\title{
Hypoxanthine production by ischemic heart demonstrated by high pressure liquid chromatography of blood purine nucleosides and oxypurines
}

\author{
E. Harmsen *, J.W. de Jong and P.W. Serruys \\ Cardiochemical and Catheterization Laboratories, Thoraxcenter, Erasmus Universit Rotterdam. \\ P.O. Box 1738, 3000 DR Rotterdam (The Netherlands)
}

(Received November 25th, 1980)

\section{Summary}

An isocratic high pressure liquid chromatographic system was developed for the estimation of purine nucleosides and oxypurines in blood. Use was made of a reversed-phase column. Nucleotides derived from erythrocytes affected the separation; these compounds were removed with $\mathrm{Al}_{2} \mathrm{O}_{3}$. The recovery of the whole clean-up procedure exceeded $75 \%$, and the lower detection limit of the assay for blood metabolites was $0.1 \mu \mathrm{mol} / 1$. In 6 healthy volunteers, non-resting, the following blood concentrations (mean values \pm S.D. in $\mu \mathrm{mol} / \mathrm{l}$ ) were observed: adenosine $(<0.1)$, inosine $(0.2 \pm 0.1)$, hypoxanthine $(2.2 \pm 1.3)$ and xanthine $(0.2 \pm 0.1)$. In plasma and serum the total amount of these compounds was 1.9 and 5.4 times higher, respectively, presumably due to nucleotide breakdown during blood processing. The myocardial arterial-venous differences of blood purine nucleosides, oxypurines and lactate were subsequently measured in blood samples from 13 patients with angiographically documented ischemic heart disease, undergoing an atrial pacing stress test. No significant release of adenosine, inosine and xanthine by the heart was detectable in this study. The myocardial arterial-venous difference of lactate changed from $0.01 \pm 0.03 \mathrm{mmol} / 1$ (mean \pm SEM) at rest, to $-0.10 \pm 0.04$ mmol $/ 1$ during pacing $(p<0.002)$. Relatively larger changes were observed for hypoxanthine: pacing increased the arterial-venous difference from $-0.01+0.05$ to $-0.51 \pm 0.17 \mu \mathrm{mol} / 1(p<0.02)$. We conclude that the high pressure liquid chromatographic assay of blood hypoxanthine is a useful tool in the diagnosis of ischemic heart disease.

\footnotetext{
* To whom correspondence should be addressed.
} 


\section{Introduction}

During and after hypoxia or ischemia, there is in the heart, as well as in other muscles, excessive ATP breakdown. This degradation of ATP causes an efflux of breakdown products, which are able to pass through the cell membrane, and are released into the blood. The purine derivatives adenosine, inosine and hypoxanthine are thought to be markers for ischemia (for a review, see ref. [1]). Because of high activities of adenosine deaminase (EC 3.5.4.4; ADA) and nucleoside phosphorylase (EC 2.4.2.1; NP), and low or non-detectable amounts of xanthine oxidase (EC 1.2.3.2; XO) in the heart and blood, hypoxanthine seems very promising as marker for myocardial ischemia [2,3]. Enzymatic purine determinations [4,5] are timeconsuming and do not differentiate between hypoxanthine and xanthine. Recently high pressure liquid chromatography (HPLC) came into use for the determination of nucleosides and purine bases in urine, plasma and serum [6-8]. We have developed a method to determine these compounds in blood, and have compared the levels of adenosine, inosine, hypoxanthine and xanthine in blood, plasma and serum. With the assay we demonstrated the myocardial release of hypoxanthine in patients with angiographically documented ischemic heart disease, undergoing an atrial pacing stress test.

\section{Materials and methods}

Enzymes (XO, $13 \mathrm{U} / \mathrm{ml}$; NP, $10 \mathrm{U} / \mathrm{ml}$; ADA, $140 \mathrm{U} / \mathrm{ml}$ ) were purchased from Boehringer-Mannheim, F.R.G.; $\mathrm{CH}_{3} \mathrm{OH}$ (Uvasol), $\mathrm{NH}_{4} \mathrm{H}_{2} \mathrm{PO}_{4}, \mathrm{KOH}, \mathrm{K}_{2} \mathrm{CO}_{3}$, adenosine, hypoxanthine and uridine from Merck (Darmstadt, F.R.G.). Uric acid was supplied by Sigma (Saint Louis, MO, U.S.A.), and the other standards by Koch-Light (Colnbrook, Bucks., U.K.). $\mathrm{Al}_{2} \mathrm{O}_{3}$ came from Desaga, Heidelberg, F.R.G. $\left[\mathrm{U}^{14} \mathrm{C}\right]$ nucleosides and oxypurines were obtained from The Radiochemical Centre (Amersham, Bucks., U.K.; spec. act. 50-60 Ci/mol). $\mathrm{HClO}_{4}$ was supplied by Merck, and used as a $1.3 \mathrm{~mol} / 1$ dilution. Water was purified with the MilliRo4/Milli-Q system (Millipore Co., Bedford, MA, U.S.A.).

\section{Blood sample treatment}

Blood $(2.0 \mathrm{ml})$ was deproteinized immediately with an equal volume of $\mathrm{HClO}_{4}$ as described by Remme et al. [2]. Plasma was prepared by adding $3 \mathrm{ml}$ blood to a heparinized tube and immediate centrifugation for $15 \mathrm{~min}$ at $3000 \times \mathrm{g}\left(4^{\circ} \mathrm{C}\right)$. Serum was prepared from $3 \mathrm{ml}$ blood which had been allowed to clot at room temperature for $30 \mathrm{~min}$ and subsequent centrifugation. Plasma and serum were also deproteinized with equal volumes of $\mathrm{HClO}_{4}$. After centrifugation, the supernatant fluids were stored at $-20^{\circ} \mathrm{C}$. The acid extracts were brought to $\mathrm{pH} 5-7$ at $0^{\circ} \mathrm{C}$ with an automatic titration device (Radiometer, Copenhagen) using 150-200 $\mu \mathrm{l} 6 \mathrm{~mol} / 1$ $\mathrm{KOH}+1 \mathrm{~mol} / 1 \mathrm{~K}_{2} \mathrm{CO}_{3} . \mathrm{KClO}_{4}$ was spun down for $10 \mathrm{~min}$ at $12000 \times \mathrm{g}$ at $4^{\circ} \mathrm{C}$. For plasma and serum $200 \mu \mathrm{l}$ of these extracts were directly injected onto the HPLC column. For whole blood extracts, removal of nucleotides appeared to be necessary. We used the method of Chatterjee et al. [9], with some minor differences. We applied 
$1.5 \mathrm{ml}$ of the deproteinized, neutralized blood sample onto a pre-washed column of $\mathrm{Al}_{2} \mathrm{O}_{3}(0.6 \mathrm{~g})$ in a Pasteur pipette, and eluted it with $5.0 \mathrm{ml} 10 \mathrm{mmol} / 1 \mathrm{Tris} / \mathrm{HCl}$, $\mathrm{pH}$ 7.4. For faster elution, a vacuum was applied; with a 1225 sampling manifold (Millipore Co.) 12 samples were treated at the same time. With standards (about 10 $\mu \mathrm{mol} / 1$ oxypurines and nucleosides, and about $5 \mathrm{mmol} / 1$ nucleotides), we found recoveries exceeding $90 \%$, whereas the nucleotides were fully retained. These values are in close agreement with values in the literature [9].

\section{Recovery studies for blood treatment}

To carry out recovery studies, it is necessary to inactivate first the purine metabolizing enzymes in the blood. We achieved this by rapid mixing of blood with cold $\mathrm{HClO}_{4}$. This procedure is comparable to the determination of recoveries after inactivation of enzymes by freeze-clamping heart tissue, or removal of cells from blood, and subsequent addition of standards [4,5,7,8,10-12]. If radioactive standards were used $10 \mu 1{ }^{14} \mathrm{C}$-labelled hypoxanthine, xanthine, inosine or adenosine were mixed with $10 \mathrm{ml} \mathrm{HClO}_{4}$. For the determination of radioactivity $50 \mu 1$ aliquots were mixed with $10 \mathrm{ml}$ Insta-gel (Packard Instr. Co., Downers Grove, IL, U.S.A.) and counted with a Packard Tricarb 2650 liquid scintillation counter.

\section{High pressure liquid chromatography}

A Varian 8520 high pressure liquid chromatograph (Varian, Palo Alto, CA, U.S.A.) was used with a pneumatic sampling device (Valco Instr. Co., Houston, TX, U.S.A.), an autosampler (Varian), a Model 440 fixed wavelength UV-detector (Waters Assoc., Milford, MA, U.S.A.) and a chromatographic data system C-111 (Varian). A $4 \mathrm{~mm}$ I.D. $\times 30 \mathrm{~cm}$ prepacked $\mu$ Bondapak $/ \mathrm{C}_{18}$ column (Waters Assoc.) was used in these studies. The packing material has an average particle size of $10 \mu \mathrm{m}$ and consists of porous silica to which a monolayer of octadecyltrichlorosilane is chemically bound. Chromatographic conditions were adapted from earlier work [13]: $200 \mu 1$ samples were eluted from this column with $10 \mathrm{mmol} / 1 \mathrm{NH}_{4} \mathrm{H}_{2} \mathrm{PO}_{4} / \mathrm{CH}_{3} \mathrm{OH}$ $(10: 1, \mathrm{v} / \mathrm{v}), \mathrm{pH} 5.50$. The flow rate was $60 \mathrm{ml} / \mathrm{h}(p=80 \mathrm{bar})$.

\section{Lactate assay}

I actate was determined in acid supernatants in duplicate with an AutoAnalyzer II (Technicon, Tarrytown, NY, U.S.A.) as described by Apstein et al. [14].

\section{Statistical analysis}

Statistical analysis in Table II was performed with a two-group comparison test based on Student's $t$ distribution, and those in Table III and Fig. 5 by Student's paired $t$ test. $p$-values $<0.05$ (two-sided) were considered significant.

\section{Results}

\section{$H P L C$}

Fig. 1 represents the scparation of several nucleosides and purine bases. The lower detection limit with a $200 \mu 1$ sample loop is $0.01 \mu \mathrm{mol} / 1$; the method is linear up to 
$200 \mu \mathrm{mol} / 1$ (Fig. 2). The standard deviation at the 10,1 and $0.1 \mu \mathrm{mol} / 1$ level is $<0.12 \%,<5 \%$ and $<9 \%$, respectively $(n=9)$. Identification of the compounds in pre-purified blood samples was achieved by retention times (Fig. 3a), cochromatography of standards (Fig. 3b) and enzyme shifts (Fig. 3c), as described by Hartwick et al. [7]. The clean-up procedure of the blood samples causes a 9-fold dilution, which increased the lower detection limit in blood to $0.1 \mu \mathrm{mol} / \mathrm{l}$.

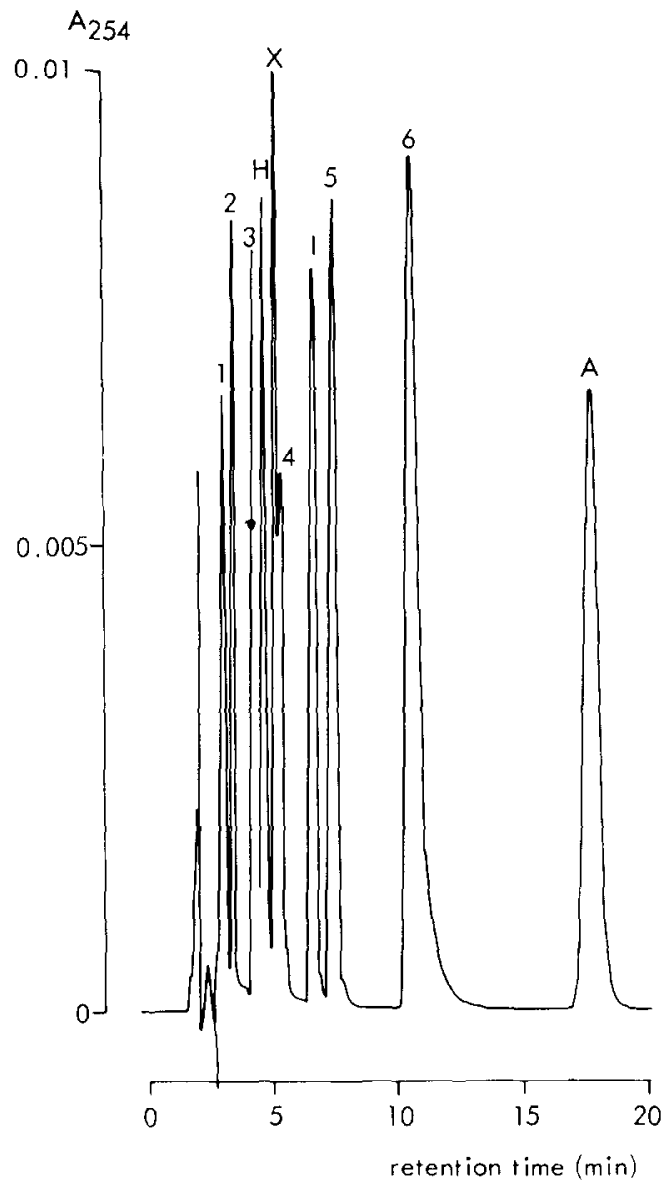

Fig. I. Isocratic HPLC separation of nucleosides and purine bases $(2-4 \mu \mathrm{mol} / \mathrm{l})$. Column: $\mu$ Bondapak $\mathrm{C}_{18}(4 \times 300 \mathrm{~mm})$. Buffer: $10 \mathrm{mmol} / 1 \mathrm{NH}_{4} \mathrm{H}_{2} \mathrm{PO}_{4} / \mathrm{CH}_{3} \mathrm{OH}(10: 1, \mathrm{v} / \mathrm{v}), \mathrm{pH} 5.50$. Flow rate: $60 \mathrm{ml} / \mathrm{h}$. Injected sample volume: $200 \mu \mathrm{l}$. 1, uric acid; 2, uracil; 3, uridine; $H$, hypoxanthine; $X$, xanthine; 4, xanthosine: I, inosinc; 5, guanosine; 6 , adenine; A, adenosine.

\section{Recoveries}

With radioactive standards the recoveries for the whole clean-up procedure exceeded 75\% (Table I). With non-radioactive standards, assayed by HPLC, we found comparable recoveries in the concentration range of our interest (Fig. 4). 


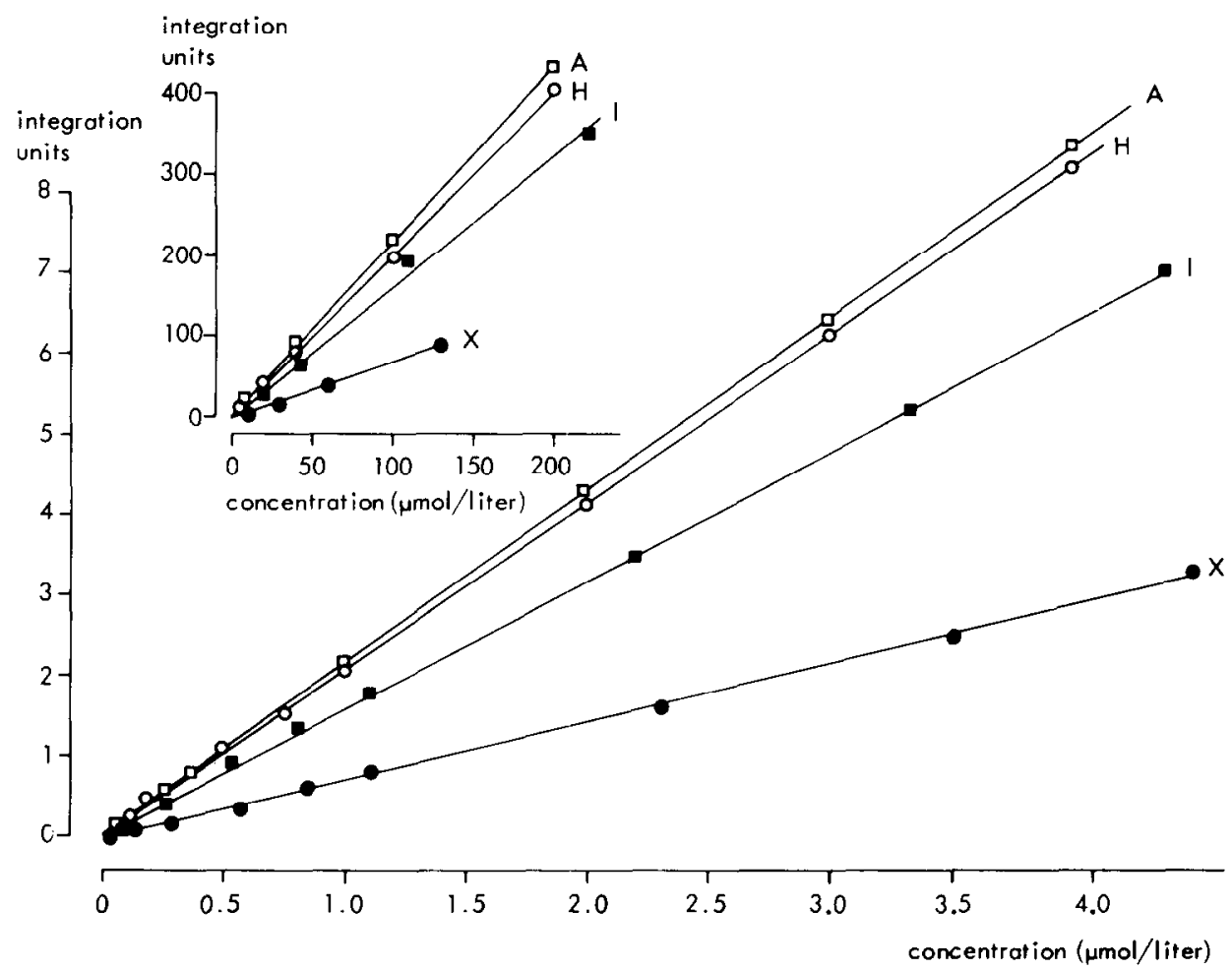

Fig. 2. Calibration curves for HPLC of hypoxanthine $(O-O) y=2.16 x-0.09, r=1.000$; xanthine

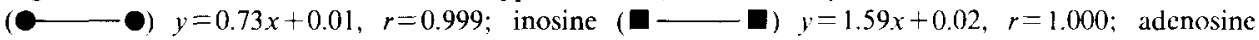
$(\square-\square) y=2.23 x-0.05, r=0.999$.

Purine derivatives in blood, plasma and serum

Six healthy non-fasting, non-resting volunteers donated venous blood. In their blood, plasma and serum, hypoxanthine, xanthine, inosine and adenosine were

\section{TABLE I}

RECOVERY OF PURINE NUCLEOSIDES AND OXYPURINES DURING SAMPLE PREPARATION

(Data represent mean values of 6 experiments \pm S.E.M.)

\begin{tabular}{llrrc}
\hline Clean-up stage & Adenosine & Inosine & Hypoxanthine & Xanthine \\
\hline \multirow{3}{*}{ Acidified human blood $(=100 \%)$} & dpm added & & & \\
\cline { 2 - 5 } & 50000 & 330000 & 230000 & 44000 \\
& recovery $(\%)$ & & & \\
Acid supernatant & $96 \pm 3$ & $106 \pm 1$ & $101 \pm 1$ & $93 \pm 4$ \\
Neutralized extract & $88 \pm 2$ & $101 \pm 2$ & $92 \pm 2$ & $99 \pm 4$ \\
Alumina eluate & $79 \pm 2$ & $91 \pm 4$ & $86 \pm 1$ & $76 \pm 6$ \\
\hline
\end{tabular}




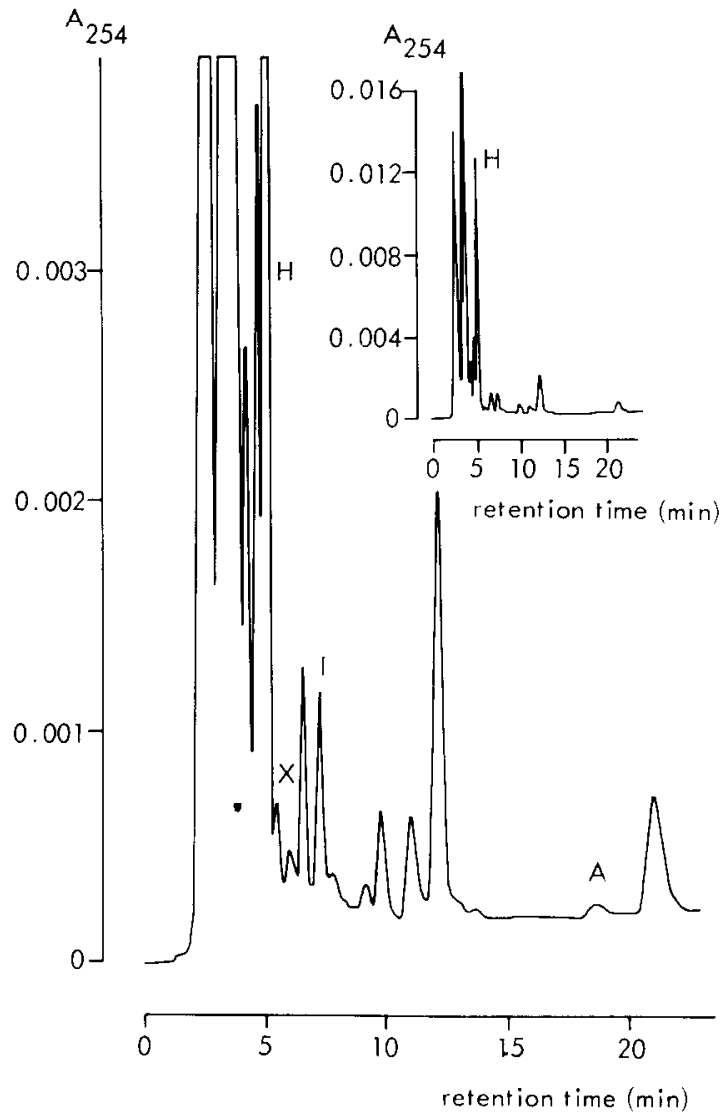

(a)

Fig. 3 ( $a, b$ and c). Chromatogram of blood from a normal donor. (a) Blood was deproteinized and purified as described under "Materials and methods". Conditions, see Fig. 1. (The upper panel represents the same chromatogram with a 4 times lower detector sensitivity.) II, hypoxanthine; X, xanthine; I. inosine; $\mathrm{A}$, adenosine.

TABLE II

CONCENTRATION OF ADENOSINE, INOSINE AND (HYPO)XANTHINE IN HUMAN BLOOD, PLASMA AND SERUM

(Data represent mean values in $\mu \mathrm{mol} / 1$ of $5-6$ volunteers \pm S.D.)

\begin{tabular}{|c|c|c|c|c|}
\hline Preparation & $\begin{array}{l}\text { Adenosine } \\
(\mu \mathrm{mol} / \mathrm{l})\end{array}$ & $\begin{array}{l}\text { Inosine } \\
(\mu \mathrm{mol} / 1)\end{array}$ & $\begin{array}{l}\text { Hypoxanthine } \\
(\mu \mathrm{mol} / \mathrm{l})\end{array}$ & $\begin{array}{l}\text { Xanthine } \\
(\mu \mathrm{mol} / 1)\end{array}$ \\
\hline Blood & $<0.1$ & $0.2 \pm 0.1$ & $2.2 \pm 1.3$ & $0.2+0.1$ \\
\hline Plasma & $<0.1$ & $0.2 \pm 0.2$ & $3.6 \pm 0.8$ & $1.1 \pm 0.7^{*}$ \\
\hline Serum & $0.9 \pm 0.2^{* \boldsymbol{\Lambda}}$ & $1.0 \pm 0.4 * \boldsymbol{~}$ & $5.6 \pm 1.9^{*}$ & $6.6+2.1^{* \boldsymbol{4}}$ \\
\hline
\end{tabular}

${ }^{*} p<0.05$ vs. blood, ${ }^{\wedge} p<0.05$ vs. plasma. 


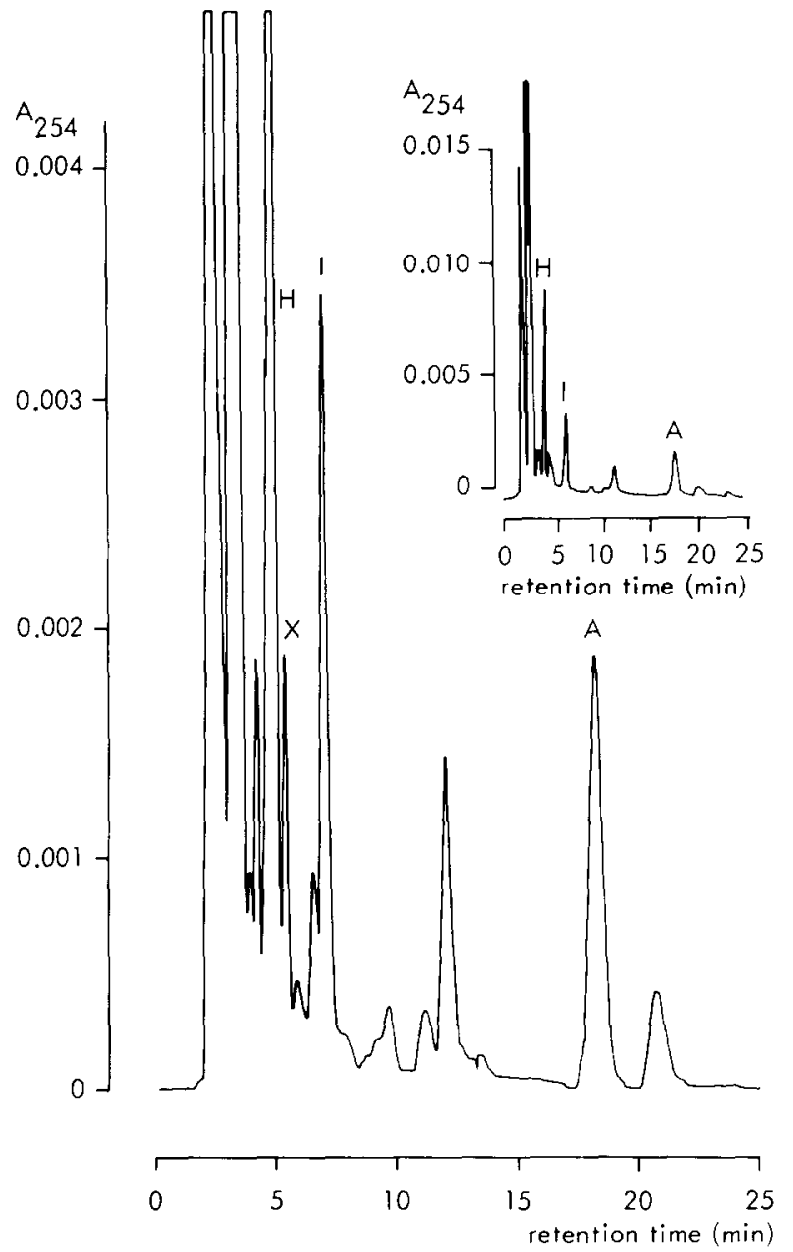

(b)

Fig. 3(b). Chromatogram as in (a), after co-injection of a solution containing hypoxanthine. xanthine, inosine and adenosine.

determined. The results are listed in Table II. As can be seen plasma shows 1.6 times higher levels of hypoxanthine and 5.5 times higher levels of xanthine than blood. Serum has significantly higher values of the AMP-catabolites. Here the values are 2.5 times (for hypoxanthine) to 33 times (for xanthine) higher, compared to blood.

Determination of blood purine nucleosides, oxypurines and lactate of patients with ischemic heart disease

Thirteen patients with angina pectoris were catheterized as described by Remme et al. [2]. The patients were fasted overnight and $36 \mathrm{~h}$ before catheterization all medication was stopped. Before catheterization 50000 IE of heparin were infused. The diagnosis, ischemic heart disease, was established by angiography (obstruction of at least one coronary artery $>50 \%$ ). Before angiography an atrial pacing stress 


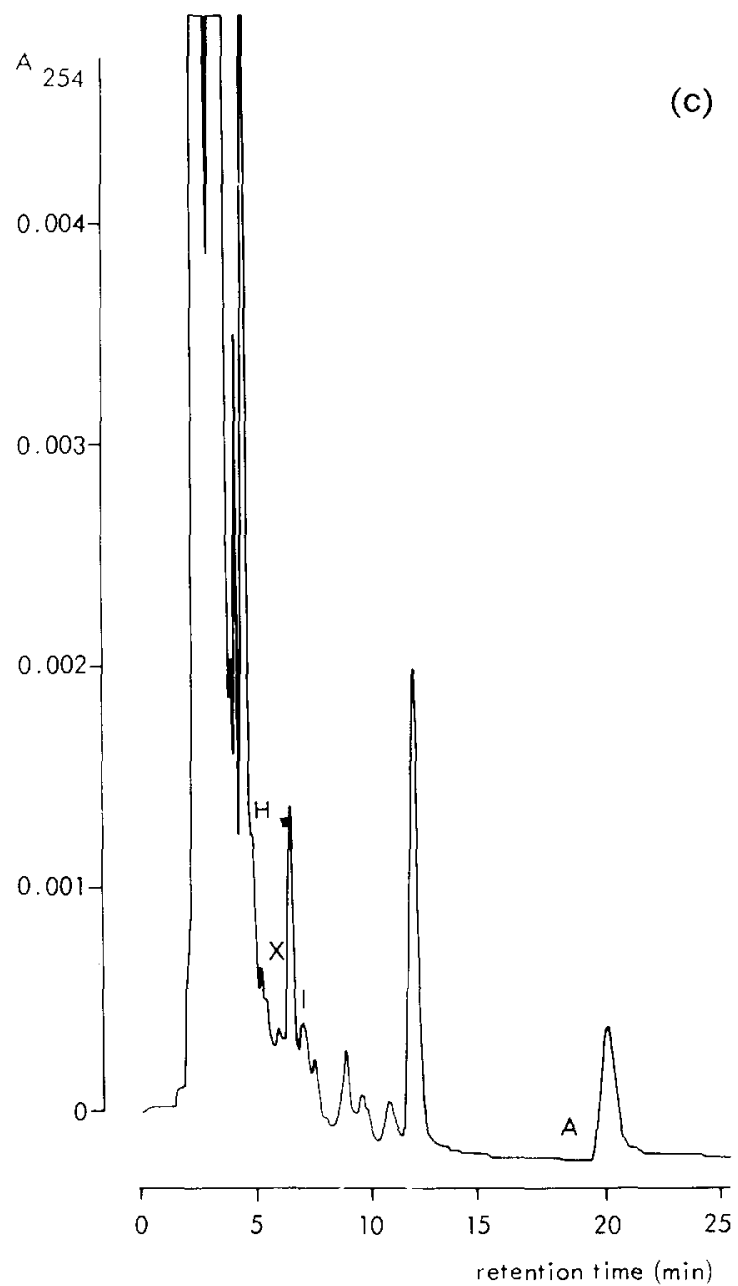

Fig. 3(c). Chromatogram as in (a), after 30 min incubation with XO, NP and ADA, $5 \mu 1$ each.

test was performed. During a control period, maximal pacing, and 5 and $20 \mathrm{~min}$ after pacing, arterial and coronary sinus blood samples were taken. At rest no significant myocardial arterial-venous hypoxanthine or lactate difference was seen (Fig. 5). During maximal pacing, a rise in coronary sinus hypoxanthine (from 0.83 to $1.43 \mu \mathrm{mol} / 1, p<0.01$ ) and lactate (from 0.87 to $0.98 \mathrm{mmol} / 1, p<0.005$ ) was observed, which fell off after pacing. The arterial levels of these compounds remained constant. The myocardial arterial-venous difference of hypoxanthine changed from $-0.01 \mu \mathrm{mol} / 1$ at rest to $-0.51 \mu \mathrm{mol} / 1(p<0.02)$ during pacing (Table III). We showed in earlier work $[2,15]$ that patients with anginal pain, but with patent coronary arteries ( $<50 \%$ obstruction), did not produce myocardial hypoxanthine. Relatively smaller changes were observed for lactate: pacing in- 

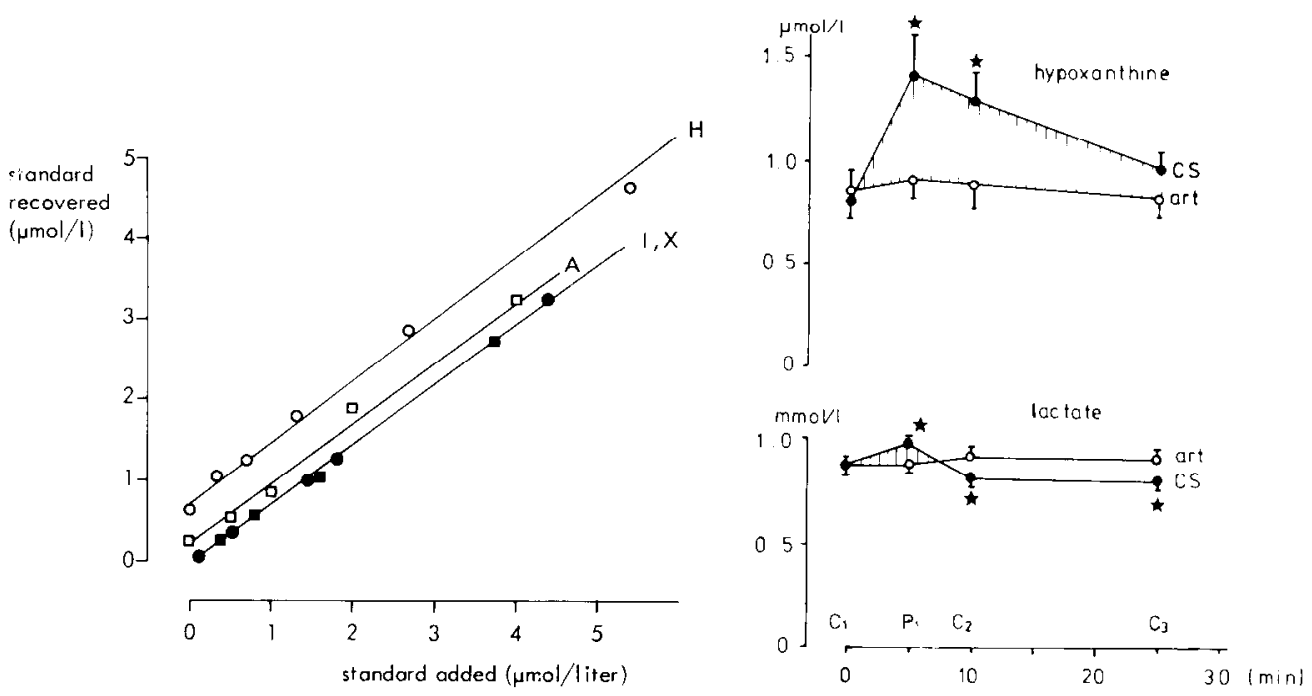

Fig. 4. Recoveries determined by HPLC. Standards were dissolved in $\mathrm{HClO}_{4}$, before blood was added. Hypoxanthine: $(\mathrm{O}-\mathrm{O}) y=0.72 x+0.77, r=0.997$; xanthine: $(-0)=0.68 x+0.01, r=0.999$; inosine: $(\mathbf{\square}-\mathbf{\square})=0.72 x-0.03, r=0.993$; adenosine: $(\square-\square) y=0.77 x+0.20, r=0.995$. For conditions, see legends to Figs. 1 and 3 .

Fig. 5. Arterial $(\mathrm{O}-\mathrm{O})$ and coronary sinus hypoxanthine and lactate levels during an atrial pacing stress test of 13 patients with ischemic heart disease. $C_{1}$, control period; $P_{1}$, maximal pacing; $\mathrm{C}_{2}$ and $\mathrm{C}_{3}, 5$ and $20 \mathrm{~min}$ after maximal pacing, respectively. Mean values are given with I S.E.M. $(\star p<0.05$ vs. arterial levels).

TABLE III

MYOCARDIAL ARTERIAL-VENOUS DIFFERENCES AND EXTRACTION VALUES OF HYPOXANTHINE AND LACTATE DURING AN ATRIAL PACING STRESS TEST OF PATIENTS WITH ISCHEMIC HEART DISEASE

The extraction value is defined as the arterial concentration minus coronary sinus concentration divided by the arterial concentration, times $100 \%$. Mean values are given \pm S.E.M. $(n=13)$.

\begin{tabular}{|c|c|c|c|c|c|}
\hline & \multirow{2}{*}{$\begin{array}{l}\text { Heart rate } \\
\text { (beats } / \text { min) }\end{array}$} & \multicolumn{2}{|l|}{ Hypoxanthine } & \multicolumn{2}{|l|}{ Lactate } \\
\hline & & $\begin{array}{l}\mathrm{A}-\mathrm{CS} \\
(\mu \mathrm{mol} / \mathrm{l})\end{array}$ & $\begin{array}{l}\text { Extraction } \\
(\%)\end{array}$ & $\begin{array}{l}A-C S \\
(\mathrm{mmol} / \mathrm{l})\end{array}$ & $\begin{array}{l}\text { Extraction } \\
(\%)\end{array}$ \\
\hline$\overline{\mathrm{C}_{1}}$ & $79 \pm 4$ & $-0.01 \pm 0.05$ & $-6 \pm 6$ & $0.01 \pm 0.03$ & $4 \pm 4$ \\
\hline$P_{1}$ & $144 \pm 4^{*}$ & $-0.51 \pm 0.17^{*}$ & $-68 \pm 18^{*}$ & $-0.10 \pm 0.04 *$ & $-9 \pm 6^{*}$ \\
\hline $\mathrm{C}_{2}$ & $78 \pm 4$ & $-0.33 \pm 0.14 *$ & $-49 \pm 14 *$ & $0.08 \pm 0.03$ & $13 \pm 6$ \\
\hline $\mathrm{C}_{3}$ & $80 \pm 4$ & $-0.15 \pm 0.08$ & $-35 \pm 14$ & $0.12 \pm 0.04 *$ & $19 \pm 6^{*}$ \\
\hline
\end{tabular}

* $p<0.05$ vs. $\mathrm{C}_{1}$.

A CS, arterial-venous difference; $C_{1}$, control period; $P_{1}$, maximum pacing: $C_{2}, 5$ min after pacing: $C_{3}$, 20 min after pacing. 
creased the arterial-venous difference from 0.01 to $-0.10 \mathrm{mmol} / 1(p<0.002$, see Table III). Significant production of lactate, calculated either as arterial-venous difference or extraction, only took place during maximal pacing. but significant hypoxanthine release was also present $5 \mathrm{~min}$ after pacing was stopped (Table III). The coronary sinus levels of adenosine, inosine and xanthine during the control period were $0.17 \pm 0.04,0.53 \pm 0.11$ and $0.20 \pm 0.14 \mu \mathrm{mol} / 1$, respectively. No significant arterio-venous differences were observed throughout the test.

\section{Discussion}

Hypoxanthine, xanthine, inosine and adenosine levels in human blood (or plasma or serum) have been measured in normal adults [7-11,16], patients with gout [17], immunological disorders [18], ischemic heart disease $[2,3,19,20]$, pregnant women [21], and children [21]. The values reported show considerable variation, which could be caused by:

(1) Differences in assay methods. The enzymatic determination of hypoxanthine, for instance, does not differentiate between hypoxanthine and xanthine.

(2) As we have shown in Table II, large differences occur in the levels of these compounds when these are measured in blood, plasma or serum from the same person. These differences can be explained by the enzymatic degradation of ATP, derived from blood cells, and ADP, released from platelets during clotting [7,8]. Furthermore xanthine, as the end-product of guanine nuclcotide catabolism, can be expected to occur in higher concentrations in plasma and serum than in blood. For instance, blood xanthosine, guanosine and guanine are rapidly converted to xanthine [22]. For this reason instant inactivation by acid seems indicated, when one wants to determine the nucleoside and oxypurine concentration in the blood.

(3) Physical activity also influences the levels of these AMP catabolites in blood. Sutton et al. [23] showed that the plasma levels of oxypurines are twice as high during and after physical training compared with control levels. Although they did not measure inosine levels in the plasma, urinary inosine during excercise is elevated tenfold, possibly indicating increased inosine levels in the blood. Therefore, if one wants to measure normal values, it is also important to define the physical state of the group under study.

We feel that measuring myocardial arterial-venous differences of blood hypoxanthine levels could give insight into the metabolic state of the heart; the method described here makes it possible to measure a number of purine metabolites in blood. The observations on the patients undergoing an atrial pacing stress test indicate that hypoxanthine is a more sensitive parameter for myocardial ischemia than adenosine, inosine, xanthine or lactate, because hypoxanthine release is more pronounced and of a longer duration than that of the other compounds.

\section{Acknowledgements}

We thank Mr. W.A.P. Breeman, Mr. J.A.J. Hegge and our colleagues at the Catheterization Laboratory for their cooperation in part of the study and Elisabeth 
Keijzer and P.Ph. de Tombe for their technical assistance. Dr. J.W. de Jong was an established investigator of the Dutch Heart Foundation when this study was carried out.

\section{References}

I De Jong. J.W. (1979) Biochemistry of acutely ischemic myocardium. In: The Pathophysiology of Myocardial Perfusion, (Schaper, W., ed.), pp. 719-750. Elsevier/North-Holland Biomedical Press, Amsterdam

2 Remme, W.J.. De Jong, J.W. and Verdouw. P.D. (1977) Effects of pacing-induced myocardial ischemia on hypoxanthine efflux from the human heart. Am. J. Cardiol. 40, 55-62

3 Gneushev, E.T., Naumova. V.V., Bogoslovsky, V.A. (1977) Content of hypoxanthine in the peripheral venous blood in infaretion and ischemia of the myocardium. Therapevt. Arkh. USSR 49, 20-24

4 Kalckar, H.M. (1947) Differential spectrophotometry of purine compounds by means of specific enzymes. J. Biol. Chem. 167, 429-443, 445-459, 460-486

5 Sumi. T. and Umeda, Y. (1979) Fluorometric determination of xanthine and hypoxanthine in tissue. Clin. Chim. Acta 95. 291-299

6 Gehrke, C.W., Kuo, K.C., Davis, G.E., Suits, R.D., Waalkes, T.P. and Borek. E. (1978) Quantitative high-performance liquid chromatography of nucleosides in biological materials. J. Chromatogr. 150 , $455-476$

7 Hartwick, R.A., Krstulovic, A.M. and Brown, P.R. (1979) Identification and quantitation of nucleosides, bases and other UV-absorbing compounds in serum, using reversed-phase high-performance liquid chromatography. II. Evaluation of human sera. J. Chromatogr. 186, 659-676

8 Wung. W.E. and Howell. S.B. (1980) Simultancous liquid chromatography of 5 -fluorouracil, uridine, hypoxanthine. xanthine, uric acid, allopurinol, and oxipurinol in plasma. Clin. Chem: 26, 1704-1708

9 Chatterjee, S.K., Bhattacharya, M. and Barlow, J.J. (19/9) A simple, specific radiometric assay for 5'-nucleotidase. Anal. Biochem. 95, 497-506

10 Pfadenhauer, E.H. (1973) Rapid determination of some plasma oxypurines using high-pressure liquid chromatography. J. Chromatogr. 81, 85-92

11 Pfadenhauer. E.H. and Tong. S.D. (1979) Determination of inosine and adenosine in human plasma, using high-performance liquid chromatography and a boronate affinity gel. J. Chromatogr. 162. $585-590$

12 Hayashi, T.T. and Gilling, B. (1970) A method for determining plasma levels of oxypurines. Anal. Biochem. 36, 343-351

13 De Jong. J.W., Keijzer, E., Uitendaal, M.P. and Harmsen, E. (1980) Further purification of adenosine kinase from rat heart using affinity and ion-exchange chromatography. Anal. Biochem. 101. 407-412

14 Apstein. C.S., Puchner, E. and Brachfeld. N. (1970) Improved automated lactate determination. Anal. Biochem. 38, 20-34

15 De Jong, J.W., Verdouw, P.D., Remme. W.J., Simoons, M.L. and Stam, H. (1980) Diagnostics of ischemic heart disease: influence of myocardial ischemia on AMP eatabolite release and hemodynamics. Clin. Cardiol. 3, 212 (Abstr.)

16 Putterman, G.J., Shaikh, B., Hallmark, M.R., Sawyer, C.G., Hixson, C.V. and Perini, F. (1979) Simultaneous analysis of substrates, products, and inhibitors of xanthine oxidase by high-pressure liquid chromatography and gas chromatography. Anal. Biochem. 98, 18-26

17 McBurney, A. and Gibson, T. (1980) Reverse phase partition HPLC for determination of plasma purines and pyrimidines in subjects with gout and renal failure. Clin. Chim. Acta 102, 19-28

18 Kuttesch, J.F.. Schmalstieg, F.C. and Nelson, J.A. (1978) Analysis of adenosine and other adenine compounds in patients with immunodeficiency disease. J. Liq. Chromatogr. 1. 97-109

19 Fox, A.C., Reed, G.E., Meilman, H. and Silk, B.B. (1979) Release of nucleosides from canine and human hearts as an index of prior ischemia. Am. J. Cardiol. 43, 52-58 
20 Kugler. G. (1979) Myocardial release of inosine, hypoxanthine and lactate during pacing-induced angina in humans with coronary artery disease. Eur. J. Cardiol. 9, 227-240

21 Manzke, H., Spreter von Kreudenstein. P.. Dorner, K. and Kruse. K. (1980) Quantitative measurements of urinary excretion of creatinine, uric acid hypoxanthine and xanthine, uracil, cyclic AMP, and cyclic GMP in healthy newborn infants. Eur. J. Pediatr. 133, 157-161

22 Jørgenson, S. (1956) Xanthine formation from guanine, guanosine or xanthosine in human blood. Acta Pharmacol. Toxicol. 12, 303-309

23 Sutton, J.R., Toews, C.J., Ward, G.R. and Fox, 1.H. (1980) Purine metabolism during strenuous muscular exercise in man. Metabolism 29, 254-260 